University of Chicago Law School

Chicago Unbound

Public Law and Legal Theory Working Papers

Working Papers

2015

\title{
The Management of Staff by Federal Court of Appeals Judges
}

G. Mitu Gulati

Richard A. Posner

Follow this and additional works at: https://chicagounbound.uchicago.edu/public_law_and_legal_theory

Part of the Law Commons

Chicago Unbound includes both works in progress and final versions of articles. Please be aware that a more recent version of this article may be available on Chicago Unbound, SSRN or elsewhere.

\section{Recommended Citation}

G. Mitu Gulati \& Richard A. Posner, "The Management of Staff by Federal Court of Appeals Judges" (University of Chicago Public Law \& Legal Theory Working Paper No. 531, 2015).

This Working Paper is brought to you for free and open access by the Working Papers at Chicago Unbound. It has been accepted for inclusion in Public Law and Legal Theory Working Papers by an authorized administrator of Chicago Unbound. For more information, please contact unbound@law.uchicago.edu. 


\title{
The Management of Staff by Federal Court of Appeals Judges
}

\section{Mitu Gulati And Richard A. Posner}

\begin{abstract}
Federal court of appeals judges have staffs consisting usually of a secretary and four law clerks; some judges have externs as (law students working part time without pay). These staffs are essential, given judicial workloads and judges' limitations. Yet not much is known about how the judges manage their staffs. Each judge knows, of course, but judges rarely exchange information about staff management. Nor is there, to our knowledge, a literature that attempts to compare and evaluate the varieties of staff management techniques employed by federal court of appeals judges. This article aims to fill that gap. It is based on interviews, some in person, most by telephone, of 75 judges drawn from a number of different federal courts of appeals.
\end{abstract}




\section{The Management of Staff by Federal Court of Appeals Judges}

\section{Mitu Gulati And Richard A. PosneR*}

\section{Introduction}

Federal court of appeals judges have staffs consisting usually of a secretary and four law clerks; some judges have interns or externs or both (law students working part time). These staffs are essential, given judicial workloads and judges' limitations. Yet not much is known about how the judges manage their staffs. Each judge knows of course, but judges rarely exchange information about staff management. The judges interviewed for this study were promised anonymity and that no information gleaned in the interviews that would enable any of the judges interviewed to be identified would be disclosed in our study. We thank the judges for their allowing us to interview them, and for their patience and candor.

William Domnarski was to be our third coauthor, but conflicting commitments forced him to resign from the project after he had conducted ten interviews. The notes of his interviews are a valuable contribution to our data, and we thank him for his participation and regret his having to curtail it.

The notes of the interviews are our raw material. What follows is a classification and description of the different management models employed by the judges. Our aim is to provide information to federal court of appeals judges, in particular newly appointed ones, about the various management models.

\section{Background and Methodology}

Information on how particular judges manage their offices is hard to come by. Someone unfamiliar with the federal appellate judiciary might expect that there would be multiple sources of this kind of information. The Federal Judicial Center offers programs to help federal judges, especially newly appointed ones, adjust to the demand of their new job, but there is little emphasis in these programs on varieties of possible staff management. There are no manuals on judicial staff management. There are a number of books and articles about judicial clerkships, but they tend not to be focused on management issues, or to be up to date. Hence the need for this study. We used a standard request letter (repro-

\footnotetext{
* Gulati is Professor of Law at Duke University School of Law. Posner is a judge of the U.S. Court of Appeals for the Seventh Circuit and a senior lecturer at the University of Chicago Law School. We thank the students in the Duke judicial studies LLM program for helpful comments. Thanks also to Kali Frampton, Alan Freedman, Mike Kenstowicz, and Xingxing Li for their research into the background literature.
} 
duced in the appendix) to inquire of 84 federal court of appeals judges (roughly half the total number of active such judges, and spread across most of the 13 circuits) whether they would allow us to interview them about their management of their staffs. Seventy-five judges agreed to be interviewed (an 88 percent response rate).

The interviews typically lasted between a half hour and an hour and focused on five aspects of judicial staff management: (1) hiring; (2) allocating work among different staff members (primarily law clerks, sometimes augmented by externs); (3) what kind of work staff did prior to oral argument; (4) what kind of work it did after oral argument; (5) what kind of workplace atmosphere the judge tried to create; and (6) the judge's post-clerkship interactions with his (or her-but we'll use the male pronoun to simplify) clerks.

Three basic models of judicial management emerged from our interviewsthe editing judge, the authoring judge, and the delegating judge. After a brief description of the existing literature, we describe the basic models discovered in our interviews, and the deviations from them.

\section{Existing Literature}

Academic research on how judges manage their staff has largely been limited to the U.S. Supreme Court, with the focus typically being the on the high degree of influence law clerks can sometimes have. ${ }^{1}$ There have been few attempts to study staff management on the federal circuit courts. Such literature as there is on the topic is largely limited to autobiographical accounts by judges and biographical accounts by judges' confidants (typically former law clerks). ${ }^{2}$ It is difficult to derive objective information from those accounts, although we do learn from them that judges give considerable thought to the degree to which they should delegate responsibility for drafting opinions to law clerks and of the choice between multi-year and single-year clerks. Most judges have a sense of how judicial icons such as Learned Hand and Henry Friendly did things--they

\footnotetext{
${ }^{1}$ E.g., ARTEMUs WARD \& DAVID L. WeIDEN, SORCERERS' APPRENTICES: 100 YeARS OF LAW ClerKS AT the United States Supreme Court (2007); TOdD C. Peppers, Courtiers of THE MARble Palace: THE Rise AND INFLUENCE OF THE SUPREME COURT LAW ClERK (2006).

2 E.g., Panel Discussion, Judges' Perspectives on Law Clerk Hiring, Utilization, and Influence, 98 MARQ. L. ReV. 441 (2014); Richard A. Posner, Judicial Opinions and Appellate Advocacy in Federal CourtsOne Judge's Views, 51 DuQueSne L. Rev. 3 (2013); Beverly B. Martin, Another Judge's Views on Writing Judicial Opinions, 51 DuQueSNe L. ReV. 41 (2013); Stephen L. Wasby, Clerking for an Appellate Judge: A Close Look, 5 Seton Hall CirCuit Rev. 19 (2008); Kermit Lipez, Judges and Their Law Clerks: Some Reflections, 22 MAINE BAR J. 112 (2007); Gilbert S. Merritt, The Decision Making Process in the Federal Courts of Appeal, 51 OHIO ST. L. J. 1385 (1990).
} 
did all their own writing, much of their own research, and used their clerks largely as sounding boards, and to do ministerial tasks. But most judges nowadays consider the Hand-Friendly model a relic of the past; that given the workload of most federal circuit judges it is an unrealistic model to follow. ${ }^{3}$

We know of only two studies that attempt to examine the system systematically. The first, by Oakley and Thompson, reports on interviews from four decades ago (1976). ${ }^{4}$ The study summarizes the results of interviews with 63 judges and 30 law clerks from four different courts in California (two federal and two state). Only six of these interviews were with federal court of appeals judges and all were from one circuit, the Ninth. ${ }^{5}$ The study reports finding that Ninth Circuit judges at the time authored most of their opinions themselves. ${ }^{6}$ Their law clerks operated mostly as research assistants and sounding boards. ${ }^{7}$ Law clerks were primarily hired for one-year stints and while externs were used, their use was not extensive. ${ }^{8}$

In 2013, Peppers, Giles and Tainer-Parkins surveyed 59 federal circuit judges (a response rate of 23 percent from the survey they sent out). ${ }^{9}$ Their focus in the survey was on law clerk hiring and utilization. Close to 100 percent of the judges surveyed had hired one-year clerks and 65 percent had hired a permanent or career clerk..$^{10}$ In comparison to what Oakley and Thompson reported from four decades earlier, many more judges are hiring multi-year clerks nowadays. Almost all of the judges surveyed in 2013 report using their clerks to draft opinions, in addition to reviewing opinions from other chambers and from their own chambers when done by other clerks. ${ }^{11}$

\section{The Standard Model - the Editing Judge}

\footnotetext{
${ }^{3}$ For a discussion of the changes in workload, as it relates to the increased reliance on clerks for matters such as drafting opinions, see Albert Yoon, Law Clerks and the Institutional Design of the Federal Judiciary, 98 MARQ. L. REV. 131 (2014).

4 JOHN BiLyeu OAKLEy \& ROBERT S. THOMPSON, LAW CLERKS AND THE JUdiCiAl PROCESS: PERCEPTIONS OF THE QUALITIES AND FUNCTIONS OF LAW CLERKS IN AMERICAN COURTS (1980).

${ }^{5} \mathrm{Id}$. at 48 .

${ }^{6}$ Id. at $94-96$.

7 Id.

8 Id.

${ }^{9}$ Todd Peppers, Michael W. Giles \& Bridget Tainer-Parkins, Surgeons or Scribes: The Role of United States Court of Appeals Law Clerks in "Appellate Triage", 98 Marq. L. Rev. 313 (2014).

${ }^{10} \mathrm{Id}$. at 317.

${ }^{11} I d$. at 321.
} 
1. Selection of law clerks. The judge hires four fresh law school graduates for one year. The initial screening of applicant resumés is typically done by the current set of law clerks, who then present the judge with a dozen or so of those applications for review. This initial screening is typically done with a focus on selecting a subset of top students from a handful of elite schools. In deciding which applicants to interview, the judge relies primarily on recommendations by law professors whom he knows personally and trusts, or on oral follow-ups to written recommendations from law professors he doesn't know, because it is widely believed by judges that written recommendations are often exaggerated but that the recommender will level with the judge over the phone. The interviews themselves are rarely substantive in the sense of the judge's testing the applicant's legal knowledge or analytical skills. Rather the focus is on seeing whether the applicant will "fit" into the culture of the office. In addition to fit, judges often care about indicia of writing skills, such as whether an applicant has worked on a law journal. Applicants are typically given a short time window (a day or so) within which they have to accept the offer, or else the job will go to someone else.

2. Staff structure. Federal court of appeals judges are allotted five personnel "slots," which they usually fill with four law clerks and one secretary. The judge will get occasional help from staff attorneys on the less important cases. Some judges use externs, but many find that the externs are more trouble than they're worth because, being mere students, they require a good deal of supervision. When externs are used it is mainly to provide in effect law clerks for the clerks, but sometimes an extern will be hired in order to benefit a local law school, with which the judge may have a close connection as an alumnus or former faculty member.

3. Assignments. Clerks tend to work primarily on the cases that will result in written opinions, though not always opinions that will be deemed precedential, and not always in cases that are orally argued rather than submitted on the briefs. Clerks generally decide among themselves which cases each one will work on. The judge rarely gets involved in the allocation of case assignments, other than to make sure that the allocation is equitable.

4. Before oral argument or submission on briefs. The law clerks prepare bench memos for all cases. The judge discusses each bench memo with the law clerk author. Law clerks will often discuss each case among themselves but the judge will discuss each case just with the law clerk who wrote the bench memo. Law clerks attend oral argument unless judge's office is in a different city, in which event at most one law clerk - the one who helped the judge prepare for the cases-will attend. 
5. After oral argument or submission on briefs. The judge reports to the law clerks on the panel's post-argument conference. The law clerk who drafted the bench memo for a case assigned by the panel to the judge will produce an opinion draft that the judge will review. He may ask the law clerk to revise further, and the exchange of opinion drafts between judge and clerk may continue for several (sometimes many) rounds. The other law clerks will then citecheck and proofread the draft approved by the judge. The opinion will then be circulated to the other members of the panel. (In some circuits, after panel approval the opinion must be circulated to the rest of the judges on the court before it can be issued.)

A distinction worth noting at this point between the editing judges and the authoring judge discussed below is that the editing judges made clear to us that they specify outcomes to their clerks and then tell them to explain and justify that outcome in the opinion draft. Few clerks, and particularly not the ambitious ones, are going to come to the judge and tell him that the arguments in favor of that outcome are simply not good enough and that therefore the judge should change his vote. The judge, by contrast, if he is writing himself, is more likely to come to that conclusion, as he is not a mere amanuensis doing what his boss wants.

6. Atmosphere. The judge will have regular meetings with the clerks as a group, either in lunches or in weekly "work" meetings. Almost all judges say that they seek to create a work atmosphere that encourages the clerks to be candid in expressing disagreement. This desire to have clerks be candid, however, is balanced against the judge's need to have the clerks understand their (lower) position in the hierarchy, take their job seriously, be perceived by others in the courthouse as professional and so on. To achieve the right balance, judges put in place rules or norms regarding matters such the office dress code and how the clerk is supposed to address the judge. Typically, the law clerks call the judge "Judge" and are told that the dress code is "business casual". The primary reason given for this formality is that it is part of inculcating a professional atmosphere, although many judges say they follow the practice because it is the accepted norm and some say that the law clerks prefer it that way. Judges also often give the clerks general contours regarding the hours they are expected to keep and vacation days; matters that are sometimes specified in a manual that is given to the law clerks when they start. Note though that, although many judges have manuals, these manuals seem to rarely get much attention from either the judge or the clerks.

7. Incentives. Judges rarely use sticks (the threat of being fired) or carrots (recommendations for a clerkship on the Supreme Court, or for appointment to a highly regarded law firm or government agency, such as a U.S. Attorney's Of- 
fice) to motivate clerks. The emphasis instead is on an egalitarian team or family concept whereby all members are treated as equally valuable in terms of their contributions.

8. Secrecy. The internal workings of the judge's office, including matters such as the deliberation process of the judge, the extent of delegation to law clerks, and how the judge interacts with his clerks, are matters not to be disclosed to the outside. "What goes on in chambers stays in chambers" is the standard mantra.

9. After the clerkship. The judge stays in touch with most of his law clerks, often providing career advice to former clerks. Photographs of past law clerks, or photo albums of them, are often placed in conspicuous places in the office. The goal is to underscore that past clerks continue to be part of the "family." Every few years the judge will have a reunion with all his former (as well as present) law clerks who are able to attend. The former clerks constitute a network that the judge helps nurture through the reunions and through other contacts with the former clerks.

We turn now to the judicial management formats that are simpler than the core - they are extremely rare-and then turn to formats that are more complex than the core; those are common.

\section{The Stripped-Down Model - the Authoring Judge}

1. Selection of law clerks. These judges do all or almost all of their own firstdraft opinion writing. Unlike the standard mode, in which the clerks are the primary authors and the judges are editors, the judge is the primary author and the clerks focus on research and editing. The criteria for selection of clerks tend to be the same as those used by the core judges, except that less weight is placed on writing skills and the interview. The judge may prefer a law clerk who has several years of practical experience, or academic study in fields other than law (preferably technical fields), before going to law school. (Many of the editing judges have similar preferences, especially a preference for clerks who have had some practical experience.) These judges are also unlikely to make exploding offers to clerkship applicants whom they interview, or indeed set any deadline for the acceptance of an offer.

2. Staff structure. The judges using this model do not think they need as much law clerk assistance as those using the standard model, and they sometimes hire less than the full complement of four law clerks. They are unlikely to hire externs.

3. Assignments. The clerks generally do not prepare bench memos or opinion drafts. Generally they decide among themselves which of them will take the lead 
in helping the judge with particular cases. The judge may ask the clerks for assistance on specific issues or the clerks may decide that it would help the judge to provide him with a memo on a particular issue.

4. Before oral argument or submission on briefs. The clerks read the briefs and do research before argument. They may do research memos for the judge and give him background materials that they think will be useful to his understanding of the case. The clerks will typically meet with the judge prior to argument to discuss the case; they will articulate their views of the case and there will be free discussion. The clerks attend the arguments unless the place of court is in a remote location.

5. After oral argument or submission on briefs. The judge will report on the panel's post-argument conference and may ask the clerks to do additional research on particular issues in the cases assigned to him (or in which he intends to write a separate opinion concurring or dissenting). The judge will draft the opinion and give it to a law clerk to review, make editorial suggestions, and think about issues that may need further exploration. On the basis of the law clerk's work, the judge is likely to revise his draft and may ask the law clerk to do yet more research. After the judge is satisfied with the opinion, a different clerk will do the citecheck, the opinon will then be issued, and a third clerk will do a careful final proofread after the panel has approved the opinion. The judge will not want the law clerks to fuss over citation format style.

6. Atmosphere. The judge is likely to have frequent lunches and chats with his law clerks. Formality is minimal regarding dress codes (dress as you wish), how the clerks address the judge (usually by first name), and rules about vacation days or work hours (generally none, so long as the clerks are productive). Judge treats the clerks as colleagues rather than as subordinates.

7. Incentives. These judges do not use incentives, positive or negative, to get their clerks to work hard. If the clerk does not get the work done, the judge is likely to do it himself.

8. Secrecy. There are no rules about what is to be secret other than the official requirement that clerks may not discuss with nonjudicial personnel any case that has not been decided yet. And the clerks are not to repeat any criticisms that judge may make of any living judge.

9. After the clerkship. There are likely to be periodic reunions. But things like photo albums of outings with the clerks and walls in the office that are lined with photographs of former clerks are unlikely. Nor is the judge likely to pay attention to nurturing a network of former clerks. 


\section{The Hierarchical Model -- The Delegating Judge ${ }^{12}$}

1. Selection of clerks. In the hierarchical model, the judge may have a junior manager to whom a portion of the management tasks are delegated. The junior manager might be one of the four one-year clerks who is chosen to be the "managing clerk", but is more typically the "career clerk" (sometimes called a "permanent clerk," but that is generally inaccurate). This junior manager coordinates, assists with, and reviews the work of the other three clerks (who usually are one-year clerks). The junior manager may also assign work on cases to the other clerks and also assist with screening and interviewing applicants for the one-year clerkships. If the junior manager is a career or multi-year clerk, his employment with the judge is unlikely to coincide with the judge's career, but he may work for the judge for a number of years. He may or may not have formal supervisory authority over the one-year clerks. In lieu of (or sometimes in addition to) a career clerk, judge may hire at least one or two clerks with prior clerkship experience, usually on a federal district court. These clerks can get started faster than the other "newbies" and can also help show the others the ropes in terms of drafting opinions and understanding the court's processes. Judge is likely to give significant weight to a personal interview, designed in part to see whether the applicant will fit in-will make a good match with the judge and the other law clerks.

2. Staff structure. The career clerk sits at the top of the hierarchy simply because of the informational advantage that he is likely to possess, even if there isn't a formal structure (although sometimes there is). If there are externs, they are likely to work primarily for the law clerks. Staff attorneys may also be used to draft the simpler opinions.

3. Assignments. The career law clerk may have assigning authority and also review all opinion drafts by the one-year clerks before they're shown to the judge. The judge or more likely the career clerk may assign cases in specialized areas that generate an especially large number of cases, such as immigration, habeas corpus, and social security disability) to a particular clerk who has relevant expertise, such as the career clerk.

4. Before oral argument or submission on briefs. The judge is likely to discuss a case before oral argument only with the law clerk who worked on that case, but

\footnotetext{
12 This is sometimes referred to as the "Becker Model" after the late Third Circuit judge Edward R. Becker. Although associated with this highly structured model, we should note that Becker himself had a reputation for maintaining a relaxed chambers atmosphere where clerks and the judge would interact frequently. One of his former clerks reports the judge taking the clerks on walks to visit his ailing mother, discussing cases along the way. Marci Hamilton, Chief Judge Edward R. Becker: A Truly Remarkable Judge, 149 U. PENN. L. ReV. 1238, 1240 (2001).
} 
generally all the clerks attend the oral arguments unless they're in a distant place.

5. After oral argument or submission on briefs. The judge reports back to the clerks on what the panel decided. The clerks then begin drafting the opinions assigned to their judge, based on the bench memos they did. Each draft opinion then goes to the judge either directly or via the career law clerk. As in the standard model, other clerks will do the citechecking and proofreading after the opinion has been approved by the judge and is ready to be circulated. Early in the year, when the one-year clerks are new, the career clerk is likely to play a larger role in the editing process than later in the year, when the new clerks have gained experience.

6. Atmosphere. The atmosphere is likely to be more formal, with the senior clerk taking on primary responsibilities for interactions with the more junior clerks. Sometimes, the secretary may serve as a conduit for communications between the clerks and the judges. Size of staff and hierarchical structure within staff (career versus one-year clerks) are likely to be correlated with formality. The formality is likely to extend also to matters such as how the judge is referred to ("judge"), interactions with the judge (limited), dress code, work hours, and vacation days.

7. Incentives. Judge may implicitly hold out the prospect of job recommendations for the best performing clerks (to the Supreme Court, the Solicitor General's Office, a U.S. Attorney's Office, or some other high status job) or (though this is rare) may hold over the clerks that threat that they might be fired.

8. Secrecy. There is likely to a strict code of secrecy regarding all matters having to do with the judge, ranging from how the office is managed to discussions about cases. Failure to comply with the codes can result in ostracism from the judge and the network of former clerks.

9. After the clerkship. Periodic reunions are likely, as is a network connecting the former clerks. Judge will probably have a dedicated wall in the common area of the office with pictures of the former clerks, or an album with those same types of pictures. And there is likely to be a strong network among the former clerks.

\section{Deviations from the Basic Models}

\section{Selection of clerks.}

a. School preferences. Some judges prefer particular schools-so much so that they may hire more than half their clerks from those schools. Others may toss out all applications from particular schools. Preferences for particular schools sometimes result from the judge's placing a high level of trust in one or 
two faculty members. Or they may feel an obligation to the local schools in their circuit or city or may have close ties to their alma mater or to a school at which they teach part time. A judge who sees clerkships as valuable training opportunities that should not all go to the students of elite institutions may hire some of his clerks from lower-ranked schools.

b. Determining fit. Some judges emphasize the importance of a law clerk's fitting in with the culture of the office. Typically, the interview and recommendations from trusted law professors are the judge's basis for determining fit, but some judges go further and have their current law clerks investigate the final applicants by doing further research, such as talking to the applicants' classmates at law school to find out what they are like to work with. Only a handful of judges explicitly test their applicants for the types of skill the judge is looking for. That is, the ability to draft a judicial opinion within a short period of time based on a defined set of materials and instructions as to desired outcome.

c. Writing samples. Some judges place so much weight on writing that they may instruct applicants to submit only writing samples that have not been through any editing process by a law review editor or anyone else. A judge who cares a great deal about consistency in his opinions, and who delegates much of the writing, may try to determine whether the clerk applicants have familiarized themselves with the judge's writing style in past opinions.

$d$. Clerk ambitions. The judge may have a preference for clerks who plan to go into public interest work, who wish to work in the local area or who have ambitions of becoming legal academics. This preference may be a function of the kinds of clerk the judge feels comfortable with or may be tied to the kinds of clerk the judge feels an obligation to provide a valuable training opportunity to. Some judges may seek out clerks who have ambitions of clerking on the Supreme Court because the judge wants to develop a reputation as a "feeder", which in turn will produce higher quality clerk applicants.

e. Team dynamics. A judge may want to have one two-year clerk and three one-year clerks, or two former district court clerks and two newbies, in order to smooth the transition from one year's law clerks to the next year's clerks. Others want little overlap between groups of clerks, so that the judge himself sets tone and agenda rather than the prior clerks. Judges may also seek to create a team of clerks that will have a diversity of background experiences, especially experiences that differ from his. The judge may also want clerks who he will be confident will get along not only with him but also with each other.

f. Hiring from the trial courts. Some judges want one or two of their clerks to have had a year of experience clerking on a trial court. Some judges have preferences for a particular trial judge or judges and may even make their offer of a clerkship contingent on the applicant's landing a job with a particular trial judge. 
Some judges, however, regard a district court clerkship as a negative in an applicant for a court of appeals clerkship.

g. Test questions. A few judges pose test questions for the applicants, whether to test the legal skills of the applicants, their ethical sense, or even their knowledge of trivia or pop culture. The judge may also want to know whether the applicant has a specific interest in this judge and such a judge may inquire into the clerk's knowledge of his opinions.

\section{Staff structure.}

a. Externs. Some judges ask externs to do the first drafts of bench memos, which will be reviewed by the law clerks before they are given to the judge. The goal is to free up the time of the law clerks to focus on opinion drafting.

$b$. Career clerks. Some judges who have career clerks have those clerks provide training and guidance to the one-year clerks. Judges may vary over their judicial careers in terms of preferences for a career clerk. Some will have a career clerk early in their careers, but dispense with them later as the judge becomes more experienced or fears excessive delegation of his judicial responsibilities to the career clerk. Others hire a career clerk as they become more senior and feel that their energy and ability are declining.

c. Secretaries. For a few judges the secretary plays an important managerial role. The secretary may interview the clerkship applicants, help them learn about the judge's preferences and habits, maybe even help them interpret and negotiate the judge's moods, and eventually organize reunions and keep the judge in touch with former clerks. At the other extreme, a judge may dispense with the traditional secretary and instead hire an aspiring law student-someone able both to perform administrative tasks and engage with the cases substantively (perhaps doing a final proofread of opinions before they leave the chambers to make sure they are readable by nonlawyers). Unlike the traditional secretary, who is a career employee, this new type of assistant is a short-term employee, staying for no more than a couple of years before heading to law school.

d. Keeping tabs. Some judges require weekly reports from their law clerks regarding the clerks' progress on the cases assigned to them. Others may use online charts, or a whiteboard in the common area in the office, that displays the clerks' individual assignments and deadlines.

3. Assignments. No significant deviations from the models described above.

4. Before oral argument or submission on briefs.

a. Guidance for the bench memo. Some judges may take a quick look at the briefs and draft a short memo (a page or so) to guide the clerks on how to craft the bench memo. Some judges want just want a short note from the clerk, sometimes as short as a page. Some judges will edit the bench memo in order to facilitate its eventual conversion (should the case be assigned to the judge) into an 
opinion. On circuits where the bench memos are shared across the judges on the panel, the question of whether the judge was involved in the production of the bench memo can be an important signal of the judge's views to the other members of the panel.

$b$. The pre-argument moot. Some judges ask their law clerks to defend their recommendations, before oral argument, concerning how they think the judge should vote to the other clerks and any externs. Such "moots" can last from a few hours to a full day session. They are thought to promote teamwork among the clerks.

c. Folders for the bench. In addition to or in lieu of bench memos clerks may be instructed to prepare a package of materials (sometimes called a "goodie basket," or just "book" - and in fact it can be book-length) that the judge can read before, and take with him to, oral argument. These folders may include key cases, relevant statutes, excerpts from the record and anything else the clerk thinks the judge might need, or that the judge has directed the clerk to include.

5. After oral argument or submission on the briefs.

a. The starter memo. Some judges draft a memo for the writing clerk on how they want the opinion to look. A judge may also decide to do the facts section of an opinion to give himself control of the narrative, or instead draft the key analytical sections.

b. Authorship preferences. Some judges write the easier opinions themselves because it can be done quickly and leaves more time for the clerks to work on the more difficult cases. Other judges may write the more difficult opinions because the clerks are inexperienced and lack the judgment to tackle difficult cases. Some do all their own dissents and concurrences because such an opinion is more personal (it is not a shared product of the panel) and therefore, these judges believe, need to speak in a more personal voice.

c. The unused draft opinion. Even judges who write most or all of their opinions may ask each clerk to draft an opinion, usually at the end of the term, as a kind of reward for the clerk's labors during the term.

d. Discussions with clerks from other chambers. Some judges encourage or at least permit the clerks to discuss their views (and maybe even those of the judge) with the clerks for other judges, on the theory that such communications can lead to better decisions.

\section{Atmosphere}

a. Elaborate reunions. Reunions vary in how elaborate they are. At one end of the spectrum are judges who have a dinner with their former clerks either in the judge's city or with clerks in a city that the judge visits in which several of his former law clerks live. At the other end of the spectrum are affairs that can last multiple days and involve multiple meals, outings, and speeches. And some 
judges have not one but two reunions a year-maybe a picnic at the end of the summer to welcome the new clerks and say goodbye to the old ones and then a more formal one during the year.

$b$. Other socializing. When judges travel to a different city with their clerks to hear oral argument, the trip can be an occasion for bonding. The judge may have multiple meals and perhaps cocktails with the clerks since they are all away from home. Sometimes a judge and his clerks may even get together for a social event with another judge and that judge's clerks.

c. Inter office socializing. Some judges may prefer their clerks have no more than minimal contract with clerks from the offices of other judges, disfavor interoffice socialization, and specifically bar communications with clerks in other offices about cases. At the other end, there are judges who not only encourage their clerks to communicate with those in other offices, but organize social events that welcome clerks from other offices. Most judges do not make any of this explicit.

d. Formality. There are judges who utilize hybrid models in between the formal and informal. Judges may have special rules for how the clerks are to dress when they attend oral arguments (more formal) or how they are to refer to the judge in private (or in social settings where only the judge and the clerks are present) as opposed to in more public settings where other court employees are present (more formality in the latter settings than the former).

7. Incentives. No significant deviations beyond the basic models.

8. Secrecy. No significant deviation beyond the basic models.

9. After the clerkship. Most judges use the team or family metaphors to describe their offices. And most judges seem to take interest in the future careers of their clerks and regret it when clerks lose touch. Some judges regard the clerks, the clerks' spouses and even clerks' children (sometimes referred to as "grandclerks") as part of the judge's extended family. And in rare cases, a judge who has clerked before may have his clerks join the reunions (and network) for his former judge.

\section{Questions for Further Research}

A number of the judges in the course of being interviewed expressed interest in learning more about certain aspects of judicial staff management. These may be areas where the Federal Judicial Center, or law school professors, may be interested in conducting research, which would be valuable to the judiciary.

1. Do different judicial management practices influence the quality or quantity of judicial output? The answer might be no, on the theory that each judge adopts the management scheme that is optimal for him or her, given circuit rules and cul- 
ture, the judge's background and experience, the judge's personality, and so forth. Or the answer might be yes-after correction for other factors, different models of judicial management (for example, whether a judge's law clerks include a career clerk as well as one-year clerks) may vary in quality as measured for example by number of citations to a judge's opinions or the speed with which the judge issues his or her opinions.

2. The economic value of a clerkship. Many judges whom we interviewed were curious about whether we knew (or planned to investigate) the economic value of a judicial clerkship to a young law student. Versions of this question included whether the value of clerkships is a function of the prestige of the court on which the clerk serves or the quality of training he receives from his judge, and whether clerkships were of greater value to students intending to be litigators rather than transactional lawyers.

3. What do the trial judges do? Some judges expressed surprise that we were not studying the management practices of district judges. District judges have heavier caseloads than court of appeals judges, yet smaller staffs. Adjustments they make to handle their higher ratio of cases to staff might provide information valuable to appellate judges.

4. The shared bench memo. In three circuits, bench memos are shared among judges. Many judges disapprove of the practice because of the incentives it creates for free riding, the extent to which it involves delegation of power to the clerks, and the social pressure to share (sharing is not mandatory).

5. Reunions. Many judges were curious about the attitudes of their colleagues-particularly those in other circuits--toward clerk reunions. 


\section{Appendix (Sample Letter)}

\section{Dear Judge X:}

I am working on a project with a law professor at Duke, Mitu Gulati, and a lawyer in Los Angeles, William Domnarski, both of whom have written extensively about judges, as have I. The new project on which we are working is one on which information is not easily available and we are hoping to collect it from informal (and confidential) conversations with a subset of judges. My aim in writing you is to ask whether you would be willing to talk to one of us, specifically Professor Gulati, who teaches at the Duke Law School. And also I want to be sure that the project we are embarked on does not violate the rules or customs or culture of any of the federal courts whose judges we may wish to interview.

The aim of the project is to provide, for the benefit of federal judges, especially but not only newly appointed ones, information about the different ways in which judges manage their staffs, consisting primarily of law clerks. We are interested in such questions as how many law clerks a judge has, how he or she selects them, their terms, whether the judge has a permanent clerk (or clerks), or a senior clerk, how the judge organizes and supervises and divides up the work among the clerks, whether the judge has interns and/or externs besides the clerks, if he is a senior judge how if at all his judicial management system has changed from when he was an active judge. The goal of the project would be to classify judicial management styles or systems in a few different categories, and to try to induce the Federal Judicial Center or some other body to distribute the results of our study to all federal judges. I know that I would have found it extremely useful as a newly appointed federal circuit judge (with no prior judicial experience) to have known more about the different management styles that federal judges were using and the considerations that entered their choice of style to adopt.

Our "survey" will be informal, consisting of short personal interviews (no written survey), unrecorded, with no identification of the judges interviewed. We shall supplement the interviews with the (limited) academic literature on judicial management, including the few articles by judges describing their judicial management system, and with a summary of the circuit or district rules that channel or constrain the judicial management systems of individual judges (for example, 
circuit rules requiring that a panel circulate its opinion to the full court before issuing it or establishing screening panels).

We do not intend to offer our personal opinions, or indeed any other opinions, on which management style or system is best. We suspect there is no "best," that variance in docket, location, judge's age and background, and other factors determine which style is best for a particular judge in a particular court. But we think judges may benefit from a catalog of the different styles--not just a newly appointed judge, but also an experienced judge who may nonetheless pick up useful tips from seeing the variety of styles "on offer," as it were.

We hope that you'll be willing to talk to Professor Gulati. I emphasize that we will neither identify the judges we interview (either by name or by indicating facts that might enable their identification), nor offer any judgments on the merits of different judicial management styles. We just want to exhibit the variety of those styles, as providing possibly useful information to the federal judiciary and to lawyers who practice in the federal courts. We aim to interview both district and circuit judges, and may also branch out and talk to some state supreme court justices or judges. ${ }^{13}$

Sincerely,

Richard A. Posner

${ }^{13}$ As of this writing, we have only conducted the portion of the inquiry relating to the federal circuit courts. 